\title{
Metabolism of lactic acid isomers in the rumen of silage-fed sheep
}

\author{
BY M. GILL, R. C. SIDDONS AND D. E. BEEVER \\ The Grassland Research Institute*, Hurley, Maidenhead, Berkshire SL6 SLR \\ AND J. B. ROWE $\dagger$ \\ ICI Pharmaceutical Division, Alderley Park, Macclesfield, Cheshire SK10 4TG
}

(Received 25 April 1985-Accepted 21 October 1985)

\begin{abstract}
1. Four mature sheep were offered perennial ryegrass (Lolium perenne, cv. S23) silage ( $885 \mathrm{~g}$ dry matter $/ \mathrm{d}$ ) at hourly intervals. The silage was well fermented with a $\mathrm{pH}$ of $4 \cdot 0$, a lactic acid content of $139 \mathrm{~g} / \mathrm{kg}$ dry matter and an organic matter digestibility of 0.766 .

2. Continuous intraruminal infusions of ${ }^{14} \mathrm{C}$-labelled sodium salts of $\left[\mathrm{U}-{ }^{14} \mathrm{C}\right]$ acetic acid, $\left[2-{ }^{14} \mathrm{C}\right]$ propionic acid, $\left[2-{ }^{14} \mathrm{C}\right]$ butyric acid and $\mathrm{D}-$ and $\mathrm{L}-\left[\mathrm{U}-{ }^{14} \mathrm{C}\right]$ lactic acid and an intravenous infusion of $\left[\mathrm{U}-{ }^{14} \mathrm{C}\right]$ glucose were made on separate occasions to estimate the fluxes of rumen acetate, propionate, butyrate and lactate as well as plasma glucose. The data were resolved by the use of appropriate four-compartment (rumen) and three-compartment (rumen-plasma) models.

3. Irreversible loss rate $(\mathrm{g} \mathrm{C} / \mathrm{h})$ of rumen acetate $(5 \cdot 32 \mathrm{~g} \mathrm{C} / \mathrm{h})$ was considerably greater than values obtained for propionate $(2 \cdot 58)$, butyrate $(2 \cdot 80)$ and lactate $(2 \cdot 91)$.

4. Total flux of lactate $(1.83 \mathrm{~mol} / \mathrm{d})$ exceeded the amount of lactate consumed in the diet $(1.37 \mathrm{~mol} / \mathrm{d})$ indicating a net synthesis of $0.46 \mathrm{~mol}$ lactate/d. Approximately 0.90 of total lactate fux was metabolized in the rumen, with $1.00 \mathrm{~mol} / \mathrm{d}$ converted to acetate, 0.57 to propionate and 0.08 to butyrate. The flux to acetate was significantly $(P<0.05)$ greater than that to propionate. Both the $\mathrm{D}$ - and $\mathrm{L}$-isomers appeared to have similar metabolic fates.

5. Lactate appeared to make no direct contribution to glucose flux in the animal, but $0 \cdot 10$ of total lactate was converted to glucose through propionate.

6. The results are discussed in relation to overall lactate metabolism, and it is suggested that almost 0.30 of ruminally digested organic matter may be fermented via lactate.
\end{abstract}

Lactic acid is an important intermediate of carbohydrate fermentation in the rumen of grain-fed animals, whilst with animals offered silage it may be as much as $150 \mathrm{~g} / \mathrm{kg}$ dry matter consumed. The biochemical pathways for the conversion of lactate to acetate, propionate and butyrate are well documented (Wood, 1961; Baldwin et al. 1962), but the factors which determine the relative amounts of lactate that are metabolized by the individual pathways are not well understood. Counotte (1981) showed that both bacterial species and rumen $\mathrm{pH}$ may influence the relative amounts of the individual volatile fatty acids (VFA) produced. In addition, it has been shown that lactic acid as such may be absorbed from the rumen (Waldo \& Schultz, 1956) and could thus contribute to glucose metabolism.

It is recognized that the efficient utilization of the end-products of digestion can be significantly influenced by the nature of the VFA produced and absorbed from the rumen in relation to the relative abundance of gluconeogenic (propionate) and non-gluconeogenic (acetate and butyrate) precursors (MacRae \& Lobley, 1982). Thus, depending on its metabolic fate in the rumen, lactic acid arising from grass silage may have a significant effect on the overall efficiency of energy utilization in silage diets.

The published evidence suggests that acetate or propionate may be the main end-product. Baldwin et al. (1962) studied lactate metabolism using isotope tracer techniques in vitro

* Now the Animal and Grassland Research Institute.

$\dagger$ Present address: Division of Animal Production, Department of Agriculture, Jarrah Road, South Perth 6151, Western Australia. 
with rumen micro-organisms isolated from silage-fed cows and found acetate to be the major end-product. In contrast, Chamberlain et al. (1983), working with grass silage fed to sheep, concluded that propionate was the principal end-product of lactate metabolism. This was based on the change in VFA proportions when lactate was either incubated in vitro with rumen fluid or infused directly into the rumen.

The present experiment was undertaken, using isotope tracer techniques in vivo, to examine the quantitative metabolism of both $\mathrm{D}$ - and $\mathrm{L}$-isomers of lactic acid in sheep offered grass silage. A preliminary report of the present work has been presented (Gill et al. 1984).

\section{MATERIALS AND METHODS}

\section{Feed}

Primary growth perennial ryegrass (Lolium perenne, cv. S23) was cut with a precision-chop forage harvester on 27 May 1980, and ensiled with formic acid (Add-F; BP Chemicals International Ltd) added at a rate of 2.3 litres/tonne fresh weight. After approximately 10 months, the silage to be used in the experiment was removed from the clamp, weighed into individual daily feeds $(3.75 \mathrm{~kg}$ fresh weight), packed in polyethylene bags and blast-frozen at $-23^{\circ}$ for $48 \mathrm{~h}$ before being stored at $-15^{\circ}$ until fed. The daily allocation of silage was thawed for at least $16 \mathrm{~h}$ before being offered to the sheep, and a representative sample was stored at $-15^{\circ}$.

\section{Animals}

Four mature Suffolk $\times$ half-bred wether sheep of live weight $64-74 \mathrm{~kg}$ were used. They were kept in metabolism crates under continuous artificial light with free access to water. Each sheep was fitted with a rumen cannula and, $24 \mathrm{~h}$ before the intravenous infusion of glucose, polyvinyl catheters (i.d. 1.00 mm; Portex Ltd, Hythe, Kent) were inserted into each jugular vein. Patency was maintained by regular flushing with heparinized saline $(9 \mathrm{~g}$ sodium chloride/l containing $250 \mathrm{IU}$ heparin $/ \mathrm{ml}$ ).

\section{Experimental procedure}

The animals were gradually introduced to silage over a $5 \mathrm{~d}$ period and were then offered silage once daily for a $7 \mathrm{~d}$ period before changing over to an hourly feeding regimen. Approximately one-third of the daily allowance was placed on the automatic feeder at 09.00 hours and the remainder at 17.00 hours.

After 1 week of hourly feeding, the sheep were harnessed to enable total collection of faeces over the following $7 \mathrm{~d}$. Faeces were weighed daily, frozen and later bulked and subsampled for chemical analysis. The subsequent measurements consisted of four intrarumen and one intravenous infusion of isotope tracers over a $22 \mathrm{~d}$ period. A minimum of $2 \mathrm{~d}$ was allowed between infusions and samples of rumen fluid, blood or both were taken before the start of each infusion to determine background radioactivity.

\section{Intrarumen infusions}

Solutions of either sodium $\left[\mathrm{U}-{ }^{14} \mathrm{C}\right]$ acetate $(0 \cdot 28 \mu \mathrm{Ci} / \mathrm{ml})$, sodium $\left[2-{ }^{14} \mathrm{C}\right]$ propionate $(0 \cdot 170 \mu \mathrm{Ci} / \mathrm{ml})$, sodium $\left[2-{ }^{14} \mathrm{C}\right]$ butyrate $(0 \cdot 14 \mu \mathrm{Ci} / \mathrm{ml})$ or sodium $\mathrm{D}$ - and $\mathrm{L}-\left[\mathrm{U}-{ }^{14} \mathrm{C}\right]$ lactate $(0.32 \mu \mathrm{Ci} / \mathrm{ml}$ ) (Amersham International, Amersham, Bucks), prepared in autoclaved water and containing $1 \mathrm{mg}$ carrier $/ \mathrm{ml}$, were continuously infused $(40 \mathrm{ml} / \mathrm{h})$ into the rumen of each sheep. The infusions were started at 07.30 hours ( 08.30 hours for the two lactate infusions) with samples being taken between 13.30 and 16.30 hours. Less time was necessary to reach steady-state with the lactate infusions, since the lactate pool in the rumen is known to turn over much faster than the VFA pools. Twelve samples of rumen fluid $(15 \mathrm{ml})$ were 
withdrawn by syringe at 15 -min intervals and immediately acidified with concentrated sulphuric acid to reduce the $\mathrm{pH}$ below 1. They were bulked in four groups of three consecutive samples and stored at $-15^{\circ}$ before chemical analysis. During the infusions of sodium propionate and sodium $\mathrm{D}$ - and L-lactate, blood samples $(20 \mathrm{ml})$ were also taken at half-hourly intervals between 13.30 and 16.30 hours for determination of glucose specific activity.

\section{Intravenous infusion}

A solution of $\mathrm{D}^{-}\left[\mathrm{U}-{ }^{14} \mathrm{C}\right]$ glucose $(0.28 \mu \mathrm{Ci} / \mathrm{ml})$, prepared in autoclaved physiological saline containing $1 \mathrm{mg}$ carrier glucose $/ \mathrm{ml}$, was continuously infused $(20 \mathrm{ml} / \mathrm{h})$ into the right jugular vein of each sheep. The infusion was started at 07.30 hours and blood samples $(20 \mathrm{ml})$ were taken at 30 -min intervals between 14.00 and 16.30 hours via the catheter placed in the left jugular vein and placed immediately into heparinized tubes. The heparinized blood was deproteinized using zinc sulphate and sodium hydroxide (Somogyi, 1945).

\section{Chemical analyses}

'Toluene' dry matter content of the silage was determined by the method of Dewar \& McDonald (1961), total lactic acid by the method of Elsden \& Gibson (1954), VFA and ethanol as described by Wilson \& Wilkins (1972) and total-nitrogen and ammonia-N content as described by Siddons et al. (1979). The contribution of L-lactate to the total silage lactate was determined enzymically using L-lactate dehydrogenase (EC 1.1.1.27) (Sigma, Poole, Dorset). Organic matter (OM) content of feed and faeces was determined by ashing at $550^{\circ}$ overnight and gross energy as reported by Terry \& Osbourn (1980). The concentration of the VFA in rumen fluid was analysed by gas-liquid chromatography using the technique of Cottyn \& Boucque (1968) as modified by Stanier \& Davies (1981). The specific activities of VFA in rumen samples collected during isotope infusions were determined by liquid-liquid chromatography, as proposed by Leng \& Leonard (1965) with the modifications suggested by Rowe et al. (1982). The concentration and specific activity of lactic acid in rumen fluid were determined using a micro-diffusion procedure (Ryan, 1958). Blood glucose specific activity was determined after separation on column chromatography (Schmidt et al. 1975).

\section{Calculations}

The flows of $\mathrm{C}$ between rumen VFA and lactic acid and blood glucose were estimated by the method of analysis of isotope-tracer results using compartmental models as described by Nolan et al. (1976). Standard procedures (Nolan et al. 1976) were used for the determination of irreversible loss rates (IRL) and transfer quotients and for the development of the three- and four-compartment models.

The IRL for lactic acid obtained using D- and L-isomer infusions were statistically compared using a paired $t$ test. The major end-product of lactate metabolism was determined by pooling the values obtained from $D$ - and L-lactate infusions for the difference in flux between acetate and propionate and conducting a one-way analysis of variance. This enabled a comparison to be made between the end-products of $\mathrm{D}$ - and L-lactate metabolism and left $5 \mathrm{df}$ to test whether the flux to acetate was significantly greater than that to propionate.

\section{RESULTS}

The composition of the grass silage as offered to the sheep is shown in Table 1. Although ammonia- $\mathrm{N}$ content was high $(0 \cdot 13$ of total $\mathrm{N})$, the low $\mathrm{pH}$ and high lactic acid suggested 
Table 1. Chemical composition of the silage $(\mathrm{g} / \mathrm{kg}$ dry matter $(D M)$ unless otherwise stated)

\begin{tabular}{lc}
\hline \hline Toluene DM (g/kg fresh) & 236 \\
pH & $4 \cdot 0$ \\
Organic matter & 911 \\
Total nitrogen & $25 \cdot 0$ \\
Ammonia-N & $3 \cdot 2$ \\
Acetic acid & $15 \cdot 1$ \\
Lactic acid & $139 \cdot 3$ \\
Butyric acid & $\mathrm{ND}$ \\
Ethanol & $5 \cdot 7$ \\
Gross energy (MJ/kg DM) & $18 \cdot 5$ \\
\hline
\end{tabular}

ND, not detectable.

Table 2. Molar concentrations and irreversible loss rates of rumen acetate, propionate, butyrate and lactate and relative specific activities $(R S A)$ in secondary pools during infusions into primary pools in sheep offered grass silage

(Mean values with their standard errors for four observations)

\begin{tabular}{|c|c|c|c|c|c|c|c|c|}
\hline & \multicolumn{2}{|c|}{ Acetate } & \multicolumn{2}{|c|}{ Propionate } & \multicolumn{2}{|c|}{ Butyrate } & \multicolumn{2}{|c|}{ Lactate } \\
\hline & Mean & SEM & Mean & SEM & Mean & SEM & Mean & SEM \\
\hline Concentration (mmol/l) & $61 \cdot 3$ & $0 \cdot 40$ & $25 \cdot 1$ & 0.31 & $8 \cdot 3$ & 0.33 & 0.243 & 0.0325 \\
\hline $\begin{array}{l}\text { Irreversible loss rates } \\
(\mathrm{g} \text { carbon } / \mathrm{h})\end{array}$ & $5 \cdot 52$ & 0.789 & $2 \cdot 58$ & $0 \cdot 210$ & $2 \cdot 70$ & $0 \cdot 251$ & $\begin{array}{l}2 \cdot 56^{*} \\
2 \cdot 91 \dagger\end{array}$ & $\begin{array}{l}0 \cdot 100 \\
0 \cdot 347\end{array}$ \\
\hline $\begin{array}{l}\text { RSA in secondary pools } \\
\text { during infusions of: }\end{array}$ & & & & & & & & \\
\hline Acetate & 1.0 & - & $0 \cdot 116$ & 0.0088 & 0.417 & 0.0646 & 0 & \\
\hline Propionate & 0.049 & 0.0059 & $1 \cdot 0$ & - & $0 \cdot 109$ & 0.0083 & 0 & \\
\hline Butyrate & $0 \cdot 199$ & 0.0325 & 0.064 & 0.0079 & $1 \cdot 0$ & - & 0 & \\
\hline D-Lactate & $0 \cdot 220$ & 0.0454 & $0 \cdot 321$ & 0.0356 & 0.149 & 0.0169 & $1 \cdot 0$ & \\
\hline L-Lactate & $0 \cdot 172$ & 0.0064 & 0.337 & 0.0401 & $0 \cdot 128$ & 0.0064 & $1 \cdot 0$ & \\
\hline
\end{tabular}

* Calculated from infusion of L-lactate.

$\dagger$ Calculated from infusion of D-lactate.

that the silage was well-preserved, while the absence of butyrate indicated that the silage had not undergone clostridial fermentation. The D- and L-isomers of lactic acid were found to be present in approximately equal amounts $(1 \cdot 08: 1)$. When fed to sheep at a level of $885 \mathrm{~g}$ dry matter/d, the digestibilities of OM and gross energy were 0.766 (SEM 0.0044) and 0.740 (SEM 0.0041) respectively. Thus, the intake of digestible energy was $0.51 \mathrm{MJ} / \mathrm{kg}$ live weight ${ }^{0.75}$.

The concentrations and IRL of the VFA and lactic acid in the rumen are presented in Table 2. Total VFA concentration was $94.7 \mathrm{mmol} / \mathrm{l}$ and the molar proportions were 0.647 , 0.265 and 0.088 for acetate, propionate and butyrate respectively. Lactate concentration was much lower than that of the VFA. However, the IRL of lactate (mean of $2.74 \mathrm{~g} \mathrm{C} / \mathrm{h}$ ) was similar to that for propionate and butyrate, but all three were lower than that measured for acetate. The IRL calculated from infusion of the ${ }^{14} \mathrm{C}$-labelled D- or L-lactate isomers did not differ significantly $(P>0.05)$.

The relative specific activities of the acids, during the tracer infusions, are also shown in Table 2 and represent the proportion of each acid derived from other VFA or lactate. 


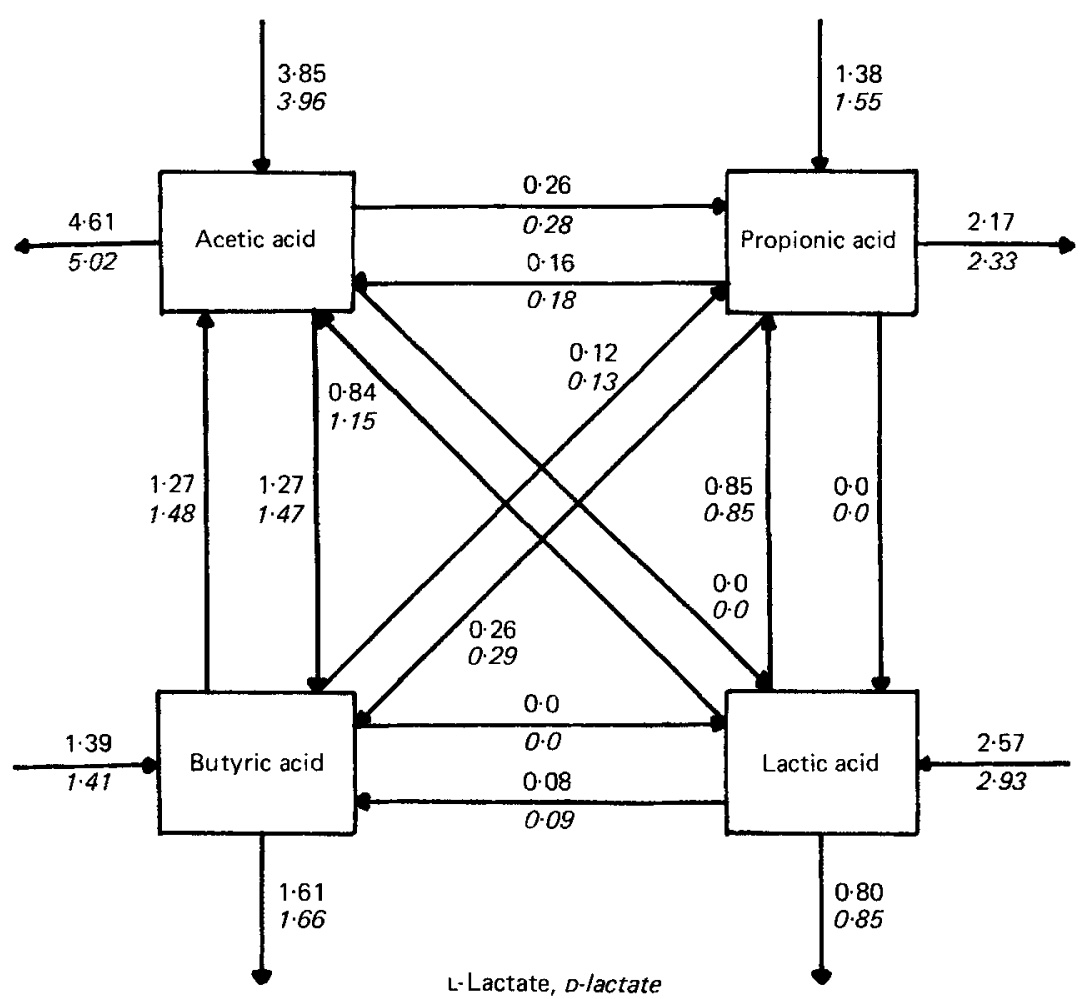

Fig. 1. Solution of four-compartmental model for fluxes ( $\mathrm{g}$ carbon $/ \mathrm{h}$ ) between acetic, propionic, butyric and lactic acids within the rumen.

Amounts of activity detected in lactate during the infusion of VFA were negligible and therefore synthesis of lactate from VFA was assumed to be zero. Proportions of acetate, propionate and butyrate $\mathrm{C}$, derived by interconversion from all other pools, amounted to $0.44,0.51$ and 0.66 respectively, while a greater proportion of propionate $(0.329)$ than either acetate $(0 \cdot 196)$ or butyrate $(0 \cdot 138)$ was derived from lactate.

The IRL and the relative specific activities for individual sheep were used to solve a four-compartmental model for the true fluxes of $\mathrm{C}$ between the different pools. The mean results are shown in Fig. 1 for both D- and L-lactate. The values for the total flux through the lactate pool ( 2.57 and 2.93 calculated from $\mathrm{L}$ - and D-isomer infusion respectively) are the same as the IRL (Table 2) since no production of lactate from the VFA was observed. However, interconversion resulted in the total fluxes through the other pools $(6.45,2 \cdot 71$, $3.13 \mathrm{~g} \mathrm{C} / \mathrm{h}$ for acetate, propionate and butyrate respectively) being higher than the corresponding IRL (Table 2). Although a greater proportion of propionate-C than of acetate-C was derived from lactate, the amount of lactate-C converted to acetate and propionate was similar $(1.00$ and $0.85 \mathrm{~g} \mathrm{C} / \mathrm{h}$ respectively) and higher than the amount converted to butyrate $(0.08 \mathrm{~g} \mathrm{C} / \mathrm{h})$. The greatest interconversion between acids was between acetate and butyrate and was of a similar magnitude in both directions.

The values derived from ${ }^{14} \mathrm{C}$-labelled $\mathrm{D}$ - and L-lactate infusions are given separately in Fig. 1, although there was no significant $(P>0.05)$ difference in the products of metabolism between the isotopes. Results showing the intake and rumen metabolism of lactate (mol/d) are presented in Table 3 . The molar flux of lactate to acetate was significantly $(P<0.05)$ greater than the flux to propionate. Total lactate flux was higher than the amount of lactate 
Table 3. Utilization of lactate in the rumen of silage-fed sheep, estimated using either $D$-or L-isomers of $\left[U-{ }^{14} C\right]$ lactic acid

(Fluxes (mol lactate/d) were estimated from the intake of silage and the solutions obtained from the four-compartment model (see Fig. 1). Mean values with their standard errors for four sheep)

\begin{tabular}{|c|c|c|c|c|}
\hline & \multicolumn{4}{|c|}{$\left[\mathrm{U}-{ }^{14} \mathrm{C}\right]$ lactate } \\
\hline & \multicolumn{2}{|c|}{ D-Isomer } & \multicolumn{2}{|c|}{ L-Isomer } \\
\hline & Mean & SEM & Mean & SEM \\
\hline Dietary intake & $1 \cdot 37$ & - & $1 \cdot 37$ & - \\
\hline Total flux through lactate pool & 1.95 & 0.231 & $1 \cdot 71$ & $0 \cdot 067$ \\
\hline $\begin{array}{l}\text { Lactate synthesized in rumen } \\
\text { (by difference) }\end{array}$ & 0.58 & - & $0 \cdot 34$ & - \\
\hline Lactate converted to: & & & & \\
\hline Acetate & $1 \cdot 15$ & $0 \cdot 196$ & 0.84 & $0 \cdot 144$ \\
\hline Propionate & 0.57 & 0.074 & 0.57 & $0 \cdot 106$ \\
\hline Butyrate* & 0.09 & 0.015 & 0.08 & $0 \cdot 016$ \\
\hline $\begin{array}{l}\text { Lactate utilization unaccounted for } \\
\text { (by difference) }\end{array}$ & $0 \cdot 14$ & - & $0 \cdot 22$ & - \\
\hline
\end{tabular}

* Assuming that 2 mol lactate are required to give $1 \mathrm{~mol}$ butyrate (see Chamberlain et al. 1983).

Table 4. Irreversible loss rate (IRL) of glucose in blood together with the relative specific activities (RSA) of glucose during rumen infusion of propionate and D- and L-lactate

(Mean values with their standard errors for four sheep)

\begin{tabular}{|c|c|c|}
\hline & Mean & SEM \\
\hline Glucose IRL ( $\mathrm{g}$ carbon $/ \mathrm{h}$ ) & $1 \cdot 66$ & $0 \cdot 0410$ \\
\hline \multicolumn{3}{|l|}{ RSA of glucose: } \\
\hline During propionate infusion & 0.437 & 0.0375 \\
\hline \multicolumn{3}{|l|}{ During infusion of: } \\
\hline L-Lactate & 0.174 & 0.0248 \\
\hline D-Lactate & 0.159 & 0.0263 \\
\hline
\end{tabular}

consumed by between 0.34 and $0.58 \mathrm{~mol} / \mathrm{d}$. Not all lactate utilization was accounted for; $0.18 \mathrm{~mol} / \mathrm{d}$ was either metabolized to products other than VFA or was absorbed. Loss by outflow would be very small due to the low concentration of lactate in rumen fluid.

The IRL of blood glucose and the relative specific activities of glucose during rumen infusions of lactate and propionate are shown in Table 4. These together with the IRL of rumen lactate and propionate (Table 2) were used to solve a three-compartmental model (Fig. 2). This showed that a negligible amount of rumen lactate was converted directly to glucose, although $0 \cdot 10$ (SEM 0.028 ) of the total lactate flux was metabolized to glucose via propionate. This represented 0.17 (SEM 0.041) of total glucose IRL (99.6 (SEM 2.43) g/d). Propionate originating from sources other than lactate was also metabolized to glucose, accounting for 0.27 (SEM 0.054) of glucose IRL. Thus, 0.44 (SEM 0.085) of total glucose IRL was synthesized from propionate, equivalent to 0.29 (SEM 0.020) of rumen propionate IRL.

\section{DISCUSSION}

Grass which is ensiled directly or after wilting without an additive is known to undergo extensive fermentation, leading to the considerable depletion of the soluble carbohydrate 


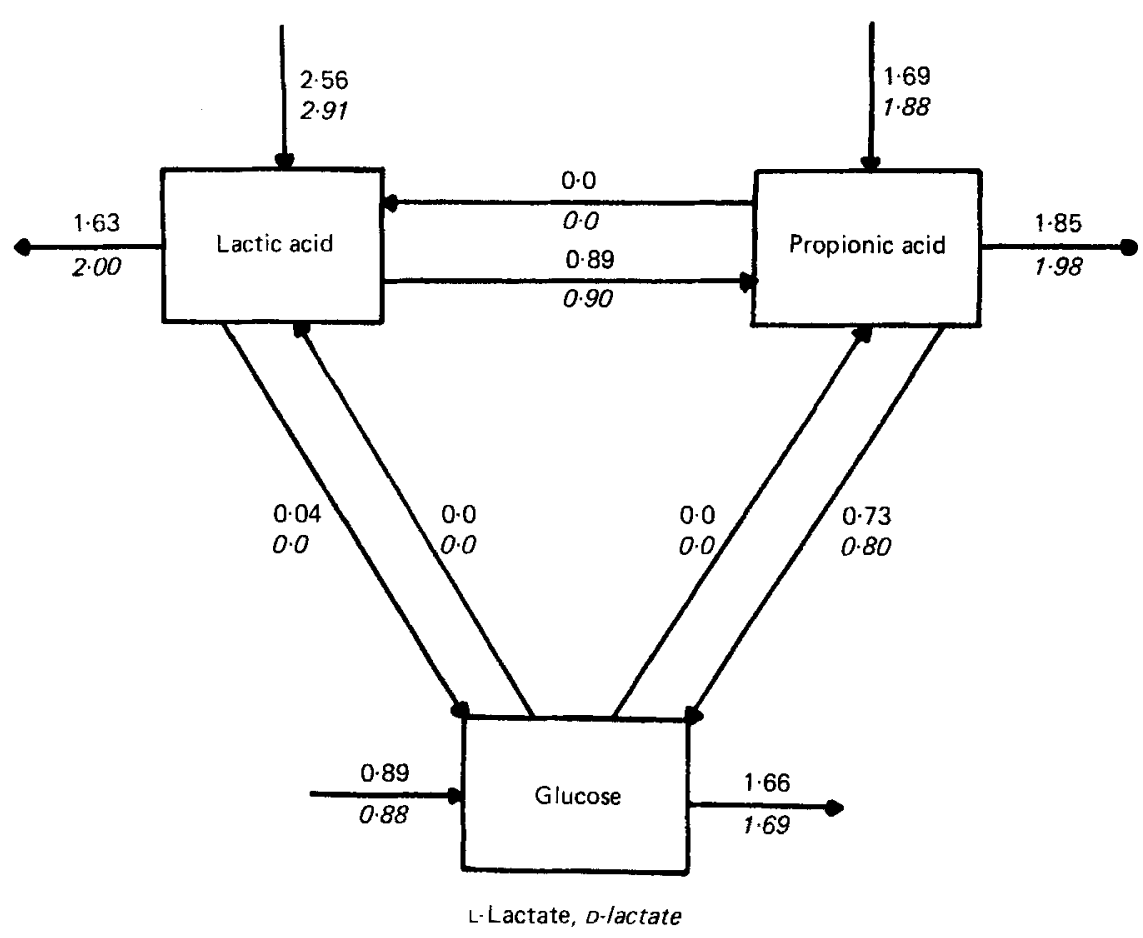

Fig. 2. Solution of three-compartmental model for fluxes (g carbon/h) between rumen lactic and propionic acids and blood glucose. Values are means of the fluxes for individual sheep calculated using the values in Tables 2 and 4.

component of the grass, with lactic acid as one of the main end-products which may comprise as much as 0.15 of the resultant silage dry matter. Whilst an essential feature in the preservation of grass by ensiling, this process may severely reduce the nutritional value of the final product. Thomas (1982) pointed out that the lower yield of energy from lactic metabolism (2 ATP/mol lactate) compared with hexose metabolism (average $4 \mathrm{ATP} / \mathrm{mol}$ hexose) in the rumen, could contribute significantly to the low synthetic efficiencies and yields of microbial biomass often noted on silage diets. Since lactic acid can also be absorbed directly from the rumen (Dunlop \& Hammond, 1965), this could also reduce the availability of energy within the rumen of silage-fed animals.

In this study, lactic acid comprised $0 \cdot 14$ of total silage dry matter, giving a daily intake of $123 \mathrm{~g} / \mathrm{d}$. De novo synthesis in the rumen contributed on average a further $4.2 \mathrm{~g} / \mathrm{d}$, indicating that $0 \cdot 20(165 \mathrm{~g} / \mathrm{d})$ of the silage OM consumed $(806 \mathrm{~g} / \mathrm{d})$ was metabolized via lactic acid. No measurements of the extent of digestion of $O M$ in the rumen were made but assuming 0.90 of digestible OM intake was initially digested in the rumen (Beever, 1980), it follows that almost $\mathbf{0 . 3 0}$ of the rumen-fermented OM would have been metabolized via lactic acid. Thus, the fate of lactate might be expected to influence not only the processes of rumen fermentation but also the efficiency of utilization of the silage energy by the tissues.

The concentration of lactic acid in the rumen was low at all times $(0.208 \mathrm{mmol} / \mathrm{l})$, indicating that lactic acid was rapidly removed from the rumen either by metabolism or absorption. The isotope results (Table 3) indicate that approximately 0.90 of total lactate was converted to VFA, suggesting that metabolism within, rather than absorption from, the rumen was the dominant mechanism for lactate removal. This agrees with the findings of Williams \& MacKenzie (1965) who suggested that the rate of lactate metabolism was 
considerably greater than the rate of absorption. No significant difference was observed between the metabolism of the D- or L-isomers of lactic acid (Table 3) as also reported by Counotte (1981) for low-lactate concentrations.

The results from the four-compartmental model (Fig. 1) suggest that in molar terms 0.55 of the total lactate metabolized was converted to acetate and only 0.31 to propionate. This partition will be influenced by the type of microbial populations present and, in particular, the lactate utilizers in the rumen and their relative metabolic activities. Counotte (1981) showed that the relative proportions of acetate and propionate produced from lactate depended on both rumen $\mathrm{pH}$ and rumen fractional outflow rate of water. At $\mathrm{pH} 6.8$ and a high dilution rate $(0.25 / \mathrm{h})$ acetate, propionate and butyrate accounted for $0.64,0.33$ and 0.03 of the total metabolism respectively. Reductions in fractional outflow rates tended to increase propionate, while a decrease in $\mathrm{pH}$ increased butyrate production. The values obtained at $\mathrm{pH} 6.8$ are very close to the molar ratios of the VFA produced from lactate at a mean $\mathrm{pH}$ of 6.5 in the present experiment, i.e. $0.62,0.35,0.03$ (calculated from Fig. 1), and this predominance of acetate in the products formed is also in agreement with the results of isotope studies by Jayasuriya \& Hungate (1959). Other workers (Emery et al. 1966; Chamberlain et al. 1983) have reported increases in the molar proportions of propionate after infusion of large amounts of lactate and inferred from this that propionate is the main end-product of lactate metabolism. However, as indicated by Counotte (1981), the end-products of metabolism when present in high concentrations may be different from those produced at lower concentrations and, as already noted, only low-lactate concentrations are normally observed on silage diets. This, together with the problems associated with interpretation of results expressed as molar proportions may have contributed to the apparent difference between the observations of Emery et al. (1966), Chamberlain et al. (1983) and the results of the present study.

As suggested earlier, it appears that very little absorption of lactate occurred in the present experiment, although the metabolic fate of the $0 \cdot 10$ of total lactate flux not converted to VFA is unknown. It may have been assimilated by micro-organisms or absorbed, but if absorbed, it was not metabolized to glucose within the tissues (Fig. 2). However, $0 \cdot 10$ of total lactate flux was converted to glucose through metabolism to propionate in the rumen and subsequent gluconeogenesis in the tissues. Overall, 0.29 of propionate flux was converted to glucose, which is lower than the value of 0.43 reported by Gill \& Beever (1982) for silage-fed calves and those of 0.43 and 0.50 reported by Judson \& Leng (1973) and Bergmann et al. (1966) repectively, for other forage-based diets. However, the value of 0.44 of total glucose flux derived from propionate is similar to the value of 0.38 reported by Gill \& Beever (1982) using $\left[2-{ }^{14} \mathrm{C}\right]$ propionate.

In summary, these results show that, on a molar basis, acetate was the major end-product of lactate metabolism in the rumen of silage-fed sheep.

The authors would like to acknowledge the technical assistance of S. B. Cammell and R. T. Evans, the veterinary supervision by A. R. Austin and the laboratory skills of D. L. Gale and Heidi Booth and the statistical advice of M. S. Dhanoa. The Grassland Research Institute was financed through the Agricultural and Food Research Council. This work formed part of a commission from the Ministry of Agriculture, Fisheries and Food.

\section{REFERENCES}

Baldwin, R. L., Wood, W. A. \& Emery, R. S. (1962). Journal of Bacteriology 83, 907-913.

Beever, D. E. (1980). In Forage Conservation in the 80's. Occasional Symposium no. 11, pp. 131-143 [C. Thomas, editor]. Hurley: British Grassland Society.

Bergmann, E. N., Roe, W. E. \& Kon, K. (1966). American Journal of Physiology 211, 793-799. 
Chamberlain, D. G., Thomas, P. C. \& Anderson, F. J. (1983). Journal of Agricultural Science, Cambridge 101, 47-58.

Cottyn, B. G. \& Boucque, C. U. (1968). Journal of Agricultural and Food Chemistry 16, 105-107.

Counotte, G. H. M. (1981). Regulation of lactate metabolism in the rumen. PhD Thesis, University of Utrecht.

Dewar, W. A. \& MacDonald, P. (1961). Journal of the Science of Food and Agriculture 12, 790-795.

Dunlop, R. H. \& Hammond, P. B. (1965). Annals of the New York Academy of Science 119, 1109-1113.

Elsden, S. R. \& Gibson, Q. M. (1954). Biochemical Journal 58, 154-158.

Emery, R. S., Thomas, J. W. \& Brown, L. D. (1966). Journal of Animal Science 25, 379-401.

Gill, M. \& Beever, D. E. (1982). British Journal of Nutrition 48, 37-47.

Gill, M., Siddons, R. C., Beever, D. E. \& Rowe, J. B. (1984). Canadian Journal of Animal Science 64, Suppl., 169-170.

Jayasuriya, G. C. N. \& Hungate, R. E. (1959). Archives of Biochemistry \& Biophysics 82, 274-287.

Judson, G. J. \& Leng, R. A. (1973). British Journal of Nutrition 29, 175-194.

Leng, R. A. \& Leonard, G. J. (1965). British Journal of Nutrition 19, 469-484.

MacRae, J. C. \& Lobley, G. E. (1982). Livestock Production Science 9, 447-456.

Nolan, J. V., Norton, V. W. \& Leng, R. A. (1976). British Journal of Nutrition 35, 127-147.

Rowe, J. B., Davies, A., Hinchcliffe, P. M. \& Broome, A. W. J. (1982). Laboratory Practice 31, $23-24$.

Ryan, H. (1958). Analyst 83, 528-531.

Schmidt, S. P., Smith, J. A. \& Young, J. W. (1975). Journal of of Dairy Science 58, 952-956.

Siddons, R. C., Evans, R. T. \& Beever, D. E. (1979). British Journal of Nutrition 42, 535-545.

Somogyi, M. (1945). Journal of Biological Chemistry 160, 69-73.

Stanier, G. \& Davies, A. (1981). British Journal of Nutrition 45, 567-578.

Terry, R. A. \& Osbourn, D. F. (1980). In Forage Conservation in the 80's. Occasional Symposium no. 11, pp. 315-330 [C. Thomas, editor]. Hurley: British Grassland Society.

Thomas, P. C. (1982). In Forage Protein in Ruminant Animal Production. Occasional Symposium no. 6, pp. 67-78 [D. J. Thomson, D. E. Beever and R. G. Gunn, editors]. Thames Ditton: British Society of Animal Production.

Waldo, D. R. \& Schultz, L. H. (1956). Journal of Dairy Science 39, 1453-1460.

Williams, V. J. \& MacKenzie, D. D. S. (1965). Australian Journal of Biological Science 18, 917-934.

Wilson, R. F. \& Wilkins, R. J. (1972). Journal of Science of Food and Agriculture 23, 377-385.

Wood, W. A. (1961). In The Bacteria, vol. 2, pp. 103-108 [I. C. Gunsalus and R. Y. Stanier, editors]. New York: Academic Press. 